Enclosure 2

Letter: Bostock to Spence

Dated May 15, 1995

K/GH-3550/R2

MARTIN MARIETRA

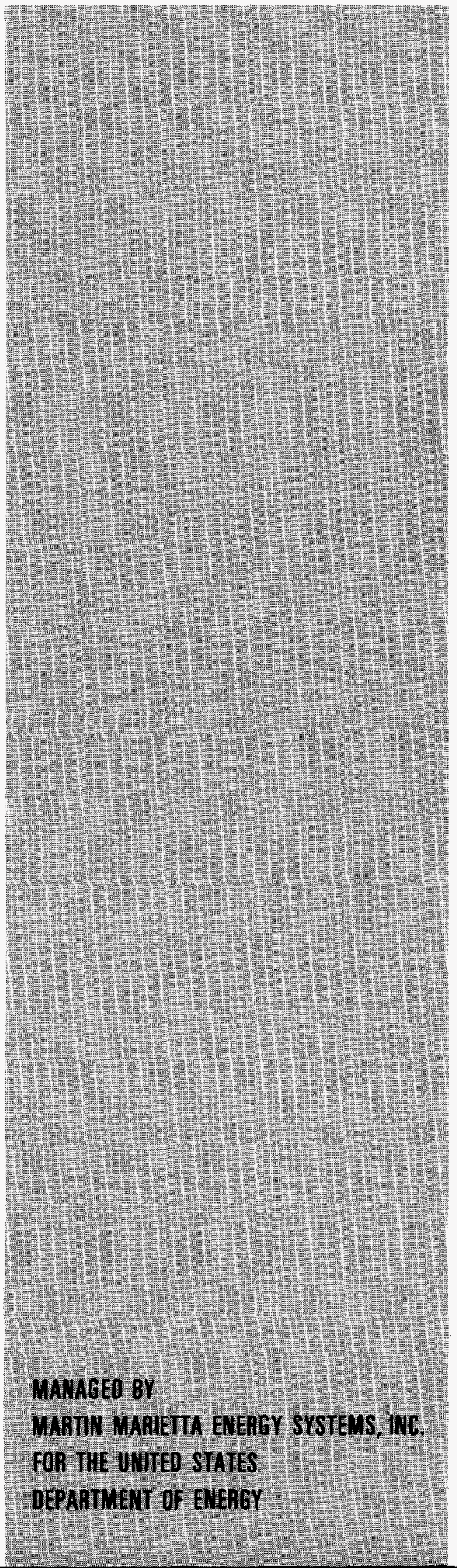

National Security Program Office

\section{ANALYSIS OF HEU SAMPLES FROM THE ULBA METALLURGICAL PLANT}

\author{
E. H. Gift \\ National Security Programs Office \\ Martin Marietta Energy Systems, Inc. \\ Oak Ridge, Tennessee \\ Initially Issued July 1994
}

Revised by A. W. Riedy

May 1995 


\section{DISCLAIMER}

This report was prepared as an account of work sponsored by an agency of the United States Government. Neither the United States Government nor any agency thereof, nor any of their employees, makes any warranty, express or implied, or assumes any legal liability or responsibility for the accuracy, completeness, or usefulness of any information, apparatus, product, or process disclosed, or represents that its use would not infringe privately owned rights. Reference herein to any specific commercial product, process, or service by trade name, trademark, manufacturer, or otherwise, does not necessarily constitute or imply its endorsement, recommendation, or favoring by the United States Government or any agency thereof. The views and opinions of authors expressed herein do not necessarily state or reflect those of the United States Government or any agency thereof. 


\section{DISCLAMMER}

Portions of this document may be illegible in electronic image products. Images are produced from the best available original document. 
National Security Program Office

\title{
ANALYSIS OF HEU SAMPLES FROM THE ULBA METALLURGICAL PLANT
}

\author{
E H Gift \\ National Security Programs Office \\ Initially Issued July 1994
}

Revised by A. W. Riedy

Prepared for the

U.S. DEPARTMENT OF ENERGY

OFFICE OF ARMS CONTROL AND NONPROLIFERATION

\section{Prepared by}

MARTIN MARIETTA ENERGY SYSTEMS, INC.

Oak Ridge, Tennessee 37831

under Contract No. DE-ACO5-84OR21400

with the

U.S. DEPARTMENT OF ENERGY

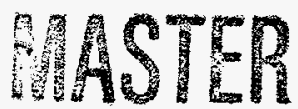


CONTENTS

Page

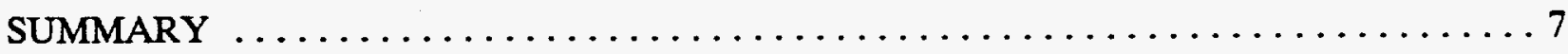

BACKGROUND AND OBJECTIVES OF ANALYSIS $\ldots \ldots \ldots \ldots \ldots \ldots \ldots \ldots$

DISCUSSION OF RESULTS $\ldots \ldots \ldots \ldots \ldots \ldots \ldots \ldots \ldots \ldots \ldots \ldots \ldots \ldots \ldots \ldots \ldots \ldots$

Uranium Isotopic Measurements $\ldots \ldots \ldots \ldots \ldots \ldots \ldots \ldots \ldots \ldots \ldots \ldots \ldots \ldots \ldots \ldots$

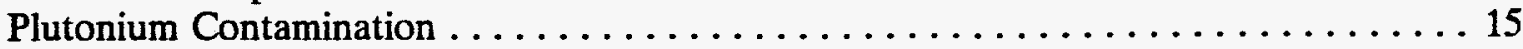

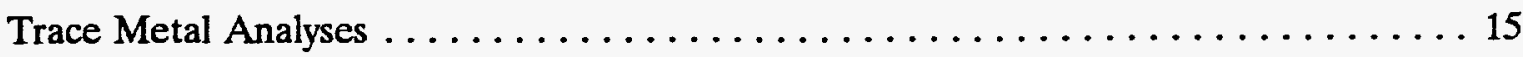

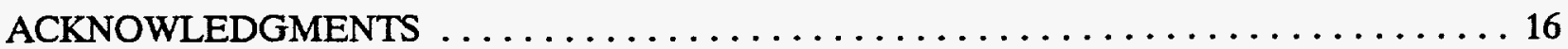





\section{SUMMARY}

In early March 1994, eight highly enriched uranium (HEU) samples were collected from materials stored at the Ulba Metallurgical Plant in Oskamen (formerly Ust Kamenogorsk), Kazakhstan. While at the plant site, portions of four of these samples were dissolved and analyzed by mass spectrograph at the Ulba analytical laboratory by Ulba analysts. Three of these mass spectrograph solutions and the eight $\mathrm{HEU}$ samples were subsequently delivered to the Oak Ridge Y-12 Plant for complete chemical and isotopic analyses. The chemical forms of the eight samples were uranium metal chips, $\mathrm{UO}_{2}$ powder, uranium/beryllium oxide powder, and uranium/beryllium alloy rods. All were declared, by the Ulba plant, to have a uranium assay of $-90 \mathrm{wt} \%{ }^{235} \mathrm{U}$. The uranium/beryllium powder and alloy samples were also declared to range from about 8 to $28 \mathrm{wt} \%$ uranium.

The chemical and uranium isotopic analyses done at the Y-12 Plant confirm the Ulba plant declarations. In addition, all samples appear to have been enriched using some reprocessed uranium, probably from recovery of uranium from plutonium production reactors. As a result, all samples contain some ${ }^{236} \mathrm{U}$ and ${ }^{232} \mathrm{U}$ and have small, but measurable quantities of plutonium. This plutonium could be the result of either contamination carried over from the enrichment process or crosscontamination from weapons material. It is not the result of direct reactor exposure. Neither the ${ }^{232} \mathrm{U}$ nor the plutonium concentrations are sufficiently high to provide a significant industrial health hazard. Both are well within established or proposed acceptance criteria for storage at the Y-12 Plant.

The trace metal analyses showed that, with the exception of beryllium, there are no trace metals in any of these HEU samples that pose a significant health hazard. 



\section{BACKGROUND AND OBJECTIVES OF ANALYSIS}

Eleven uranium-containing samples collected in Kazakhstan arrived at the Y-12 Plant in early April 1994. Eight of the samples were in solid form and three were solutions. All were contained in small glass vials $-1 \mathrm{~cm}$ in diameter and $4 \mathrm{~cm}$ long. The total uranium content was less than 15 grams. Visual examination of the eight solid samples showed that one was apparently metal chips or filings, four were powders, and three were small chunks of metal. All had been exposed to air and all exterior surfaces were fully oxidized. The analyses requested were:

1. complete uranium isotopics analyses, including ${ }^{232} \mathrm{U}$;

2. determination of uranium content;

3. transuranic alpha activity (primarily plutonium); and

4. complete trace metal analyses.

The objective of this sample program was to completely characterize the material and to determine the suitability for eventual storage of ton quantities of similar material in Y-12's HEU storage vaults.

\section{DISCUSSION OF RESULTS}

The complete uranium isotopics analyses, the uranium content, and the transuranic alpha activity, are reported in Table 1 . The trace metal analyses for all samples except one are reported in Table 2.

The uranium isotopics, excluding ${ }^{232} \mathrm{U}$, were done using thermal ionization mass spectrometry. The ${ }^{232} \mathrm{U}$ concentration was measured by counting the characteristic decay alpha spectrum from both ${ }^{232} \mathrm{U}$ and ${ }^{234} \mathrm{U}$ and computing the ${ }^{232} \mathrm{U}$ concentration by ratio with the measured ${ }^{234} \mathrm{U}$ concentration. The determination of the weight percent uranium in the sample was done primarily by isotope dilution using ${ }^{233} \mathrm{U}$ as the spike. Some were done by $\mathrm{X}$-ray analysis using internal standards. The transuranic alpha activity, primarily plutonium, was measured by counting the characteristic alpha spectrum from ${ }^{239} \mathrm{Pu}$ and ${ }^{238} \mathrm{Pu}$. The trace metal analyses were done using spark source mass spectrometry. Specific approved procedures, which are available, were followed for each of these analyses.

\section{Uranium Isotopic Measurements}

The average ${ }^{235} \mathrm{U}$ assay of all samples was $89.62 \pm 0.6 \mathrm{wt} \%$. This agrees with both the Kazakhstan declarations (i.e., within $\pm 0.7 \mathrm{wt} \%$ ) and with the mass spectrographic analysis (i.e., within $\pm 0.06 \mathrm{wt} \%$ ) done on four of the samples on the day of the collections.

All samples had significant quantities of ${ }^{236} \mathrm{U}$, the range being from 0.255 to $0.497 \mathrm{wt} \%$. This amount of ${ }^{236} \mathrm{U}$ in the $\mathrm{HEU}$ is consistent with enrichment using reprocessed uranium from plutonium production reactors as a portion of the feed. The ${ }^{234} \mathrm{U}$ content of the HEU samples ranged from 0.813 to $1.122 \mathrm{wt} \%$. This level is consistent with the enrichment of near natural uranium as the feed material. These concentrations, for both ${ }^{234} \mathrm{U}$ and ${ }^{236} \mathrm{U}$, are well within the range of HEU stored at Y-12 and that used in U.S. nuclear weapons.

The ${ }^{232} \mathrm{U}$ concentration in the samples ranged from 0 to $0.83 \mathrm{ppb}$ in the sample. The current allowable ${ }^{232} \mathrm{U}$ limit in ASTM specification C-787-90 is $0.01 \mathrm{ppb}$ in commercial $\mathrm{UF}_{6}$ made entirely from natural uranium. In enriched $\mathrm{UF}_{6}$ made from reprocessed uranium, the allowable limit is raised to $5 \mathrm{ppb}$. The analysis of the Ulba samples is well within this reprocessed uranium standard. 


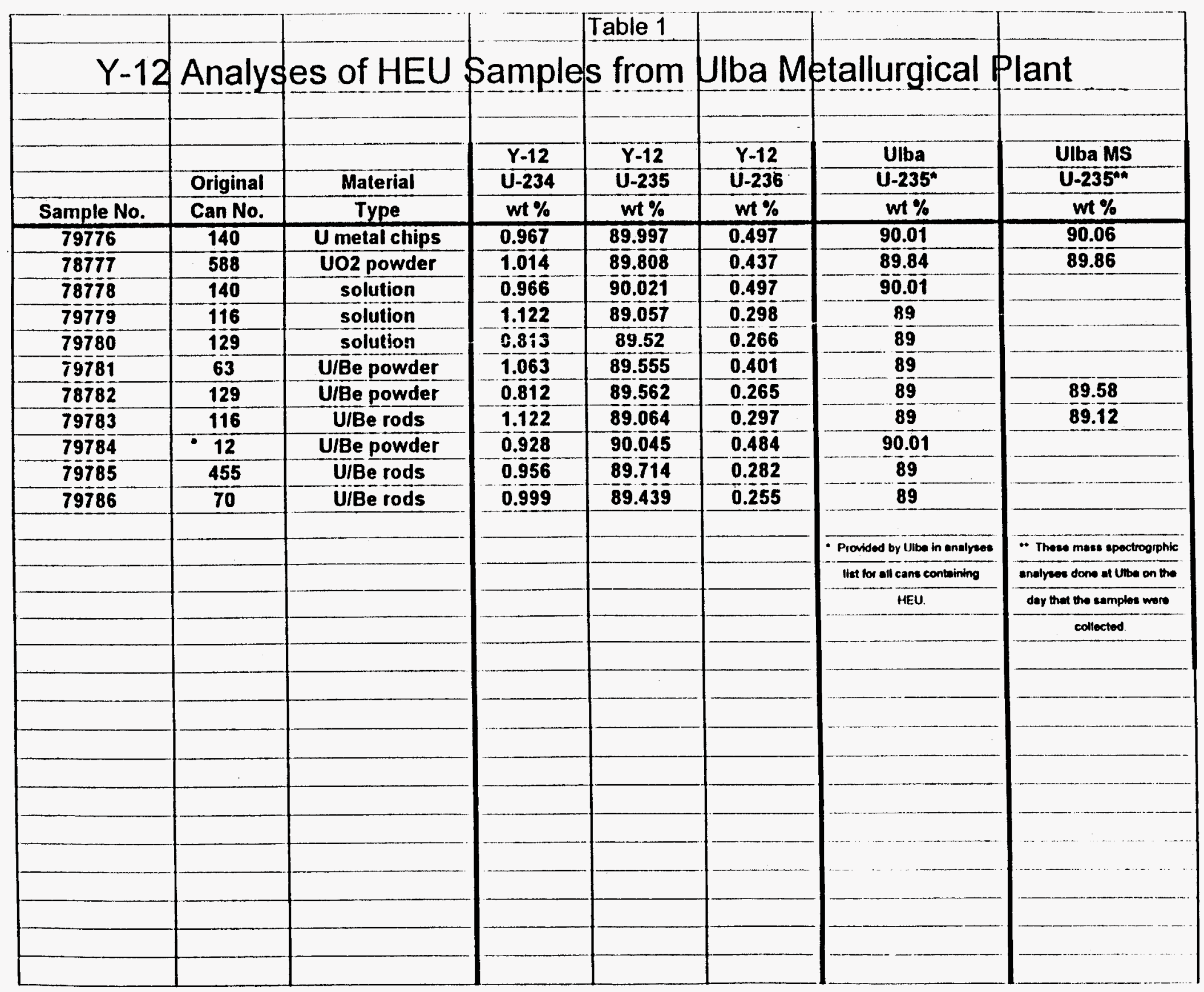




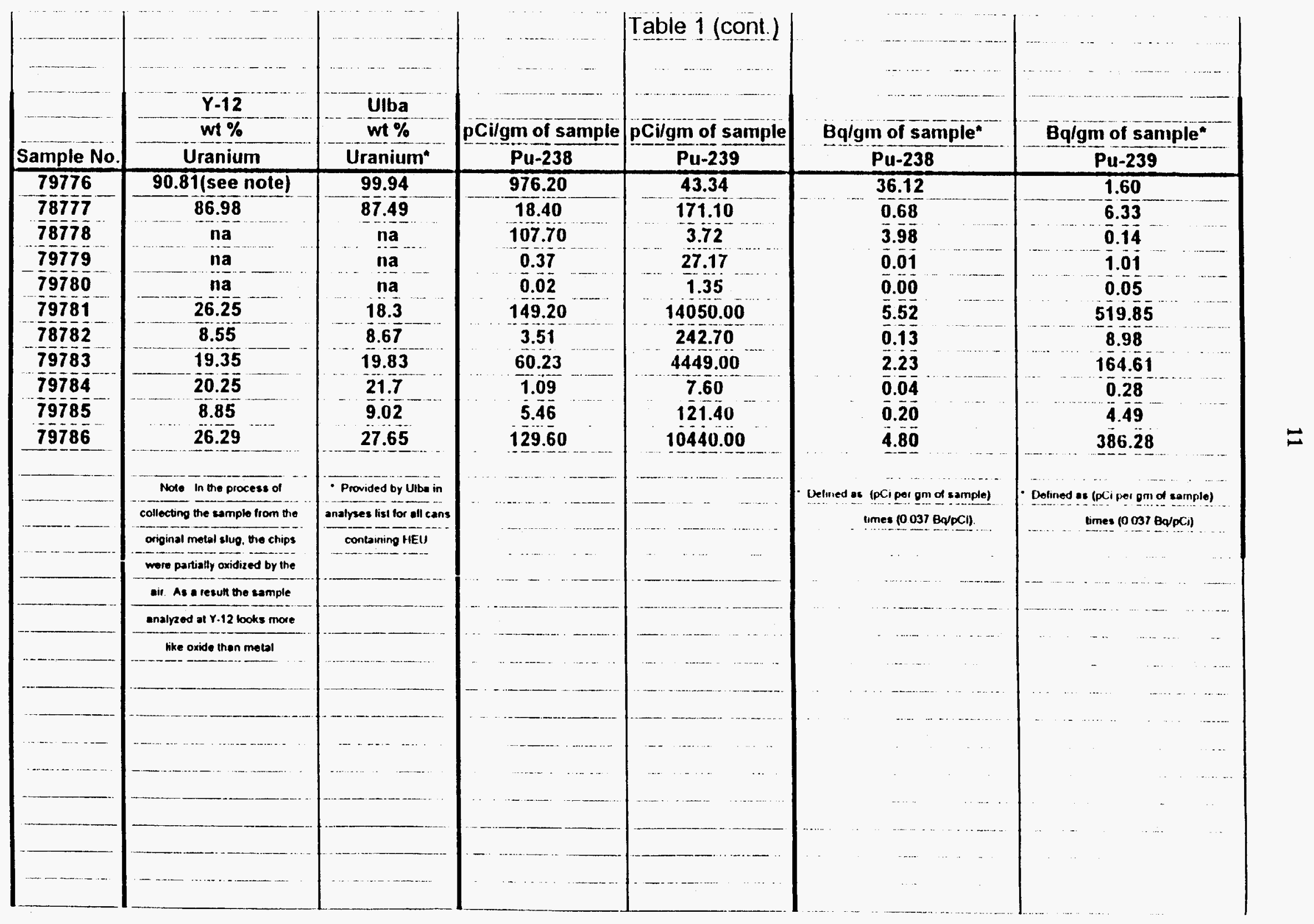




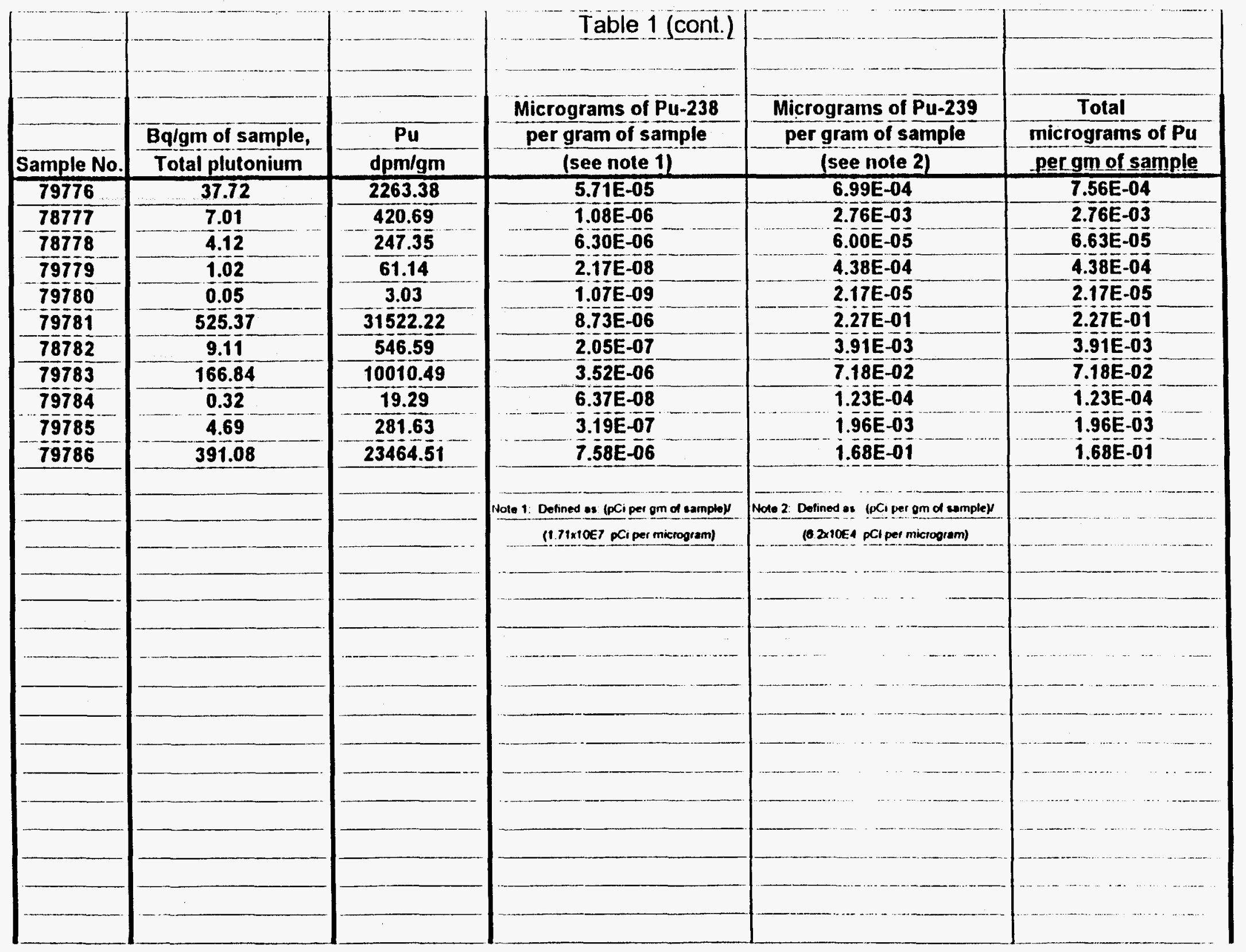




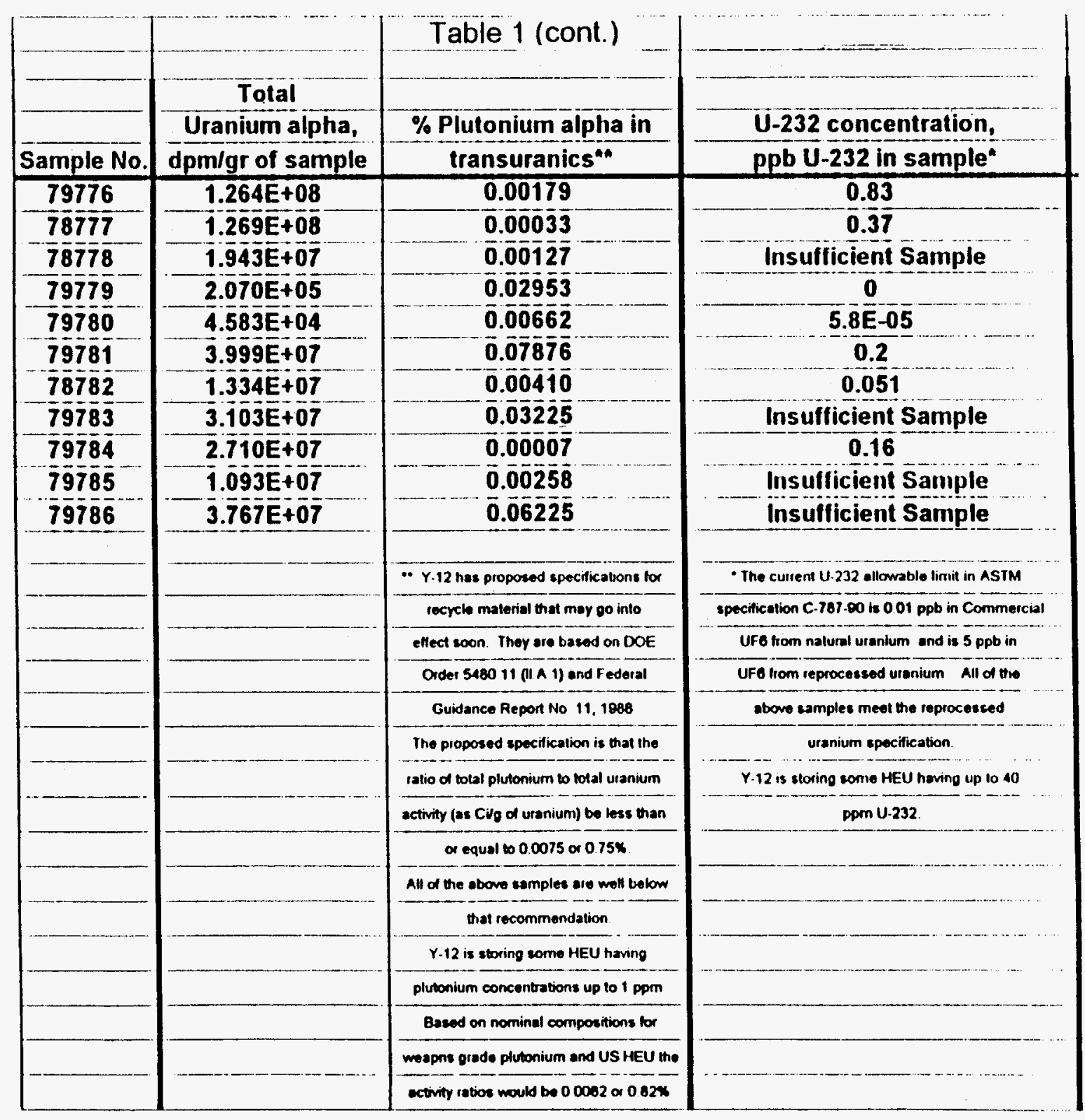


Table 2

Trace Metal Analyses of HEU Samples From the Ulba Metallurgical Plant

Parts per Million (ppm) of Sample

\begin{tabular}{|c|c|c|c|c|c|c|c|c|c|c|c|}
\hline Elernom & $\begin{array}{c}\text { Sempien No. } \\
\text { 7or7o }\end{array}$ & $\begin{array}{c}\text { Samal No. } \\
\text { Tort }\end{array}$ & $\begin{array}{c}\text { Samab No. } \\
79778\end{array}$ & 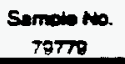 & $\begin{array}{c}\text { Semen No. } \\
\text { T8700 }\end{array}$ & $\begin{array}{c}\text { Semow No. } \\
\text { T9789 }\end{array}$ & $\begin{array}{c}\text { Somed No. } \\
79702\end{array}$ & $\begin{array}{c}\text { Semos No. } \\
\text { P.978s }\end{array}$ & $\begin{array}{c}\text { Semow No. } \\
\text { T-g7as }\end{array}$ & $\begin{array}{c}\text { Somow No } \\
\text { To7es }\end{array}$ & $\begin{array}{c}\text { Samper wo. } \\
\text { rgras }\end{array}$ \\
\hline 30 & \multirow{6}{*}{ 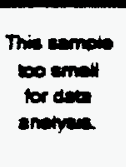 } & 7.0 & 1.00 & $>1000$ & $>1000$ & $>0.5 \%$ & $>0.5 \%$ & $>1500$ & $>1000$ & $=1000$ & $>1000$ \\
\hline$B$ & & 0.04 & $0 . \infty$ & 0.30 & 0.30 & 0.04 & 0.04 & 0.50 & 0.00 & 2.00 & 200 \\
\hline$F$ & & 0.40 & 0.20 & 0.10 & 0.10 & 0.50 & 0.50 & 1.0 & 0.70 & 0.07 & 040 \\
\hline $\mathbf{N a}$ & & 0.50 & 0.30 & 5.00 & 1.00 & 9.00 & 0.00 & & 0.80 & & \\
\hline $\mathrm{Ma}$ & & 130.00 & 1.00 & 14.00 & 1.00 & $8 . \infty$ & $2 \infty$ & 200 & 20.00 & 150.00 & 200 \\
\hline A & & 6.00 & 1.0 & 0.05 & 0.2 & 18.00 & 7200 & 3.00 & 10.00 & 1.00 & 500 \\
\hline Si & & 930.00 & 3.00 & 100 & 100 & 740.00 & $\infty 00$ & 19.00 & 84.00 & 200 & 200 \\
\hline$P$ & & 3.00 & 6.00 & 0.00 & 0.0 & 2.00 & 400 & 200 & 3.00 & 0.30 & 0.00 \\
\hline $\mathbf{s}$ & & 25.00 & 0.00 & 48.00 & 15.00 & 63.00 & 20.00 & 46.00 & 9.00 & 30.00 & 31.00 \\
\hline Cl & & 18.00 & 2.00 & 4.00 & 40 & 16.00 & 10.00 & 7.00 & $6 . \infty$ & 3.0 & 0.00 \\
\hline $\mathbf{K}$ & & 30.00 & 0.00 & 3.00 & 8.00 & 4.00 & 4.0 & & 1.00 & & \\
\hline c & & 20.0 & 5.00 & 520 & $E \mathbf{3 0 0}$ & 370.00 & 140.00 & 100.00 & 23.00 & $=1000$ & $\infty \infty$ \\
\hline Sc & & 0.30 & 0.20 & 0.08 & 0.08 & 0.40 & 0.40 & 0.05 & 0.50 & 0.05 & 0.20 \\
\hline$T$ & & 0.10 & 0.08 & 0.40 & 0.04 & 2.00 & 3.00 & 0.40 & 0.20 & 0.03 & 0.08 \\
\hline$v$ & & 0.10 & 0.0 & 0.08 & 0.08 & 0.50 & 0.10 & 0.02 & 0.20 & 0.02 & 0.08 \\
\hline $\mathrm{Cl}$ & & $4 \infty$ & 3.00 & 0.00 & 20 & 500.00 & 25.00 & 40 & 200 & $2 \infty$ & 200 \\
\hline$M n$ & & $1 . \infty$ & 0.70 & 0.40 & 100 & 49.0 & 52.00 & 2.0 & 7.00 & $19 . \infty$ & 3.00 \\
\hline Fo & & 85.00 & 7.00 & 5.00 & 12.00 & 000.00 & 230.00 & 930.00 & 110.00 & 51500 & 100.00 \\
\hline Co & & 0.20 & 0.20 & 0.04 & 0.04 & 200 & 0.20 & 0.00 & 0.20 & 70.00 & 7.00 \\
\hline $\mathrm{Ni}_{1}$ & & 18.00 & 1.00 & 200 & 3.00 & 9200 & $8 . \infty$ & 340.00 & 10.00 & -1000 & 34000 \\
\hline $\mathrm{Cu}$ & & 7.00 & 1.00 & 2.00 & 2.00 & 8.00 & 10.00 & 140.00 & 11.00 & 21000 & 170.00 \\
\hline $2 n$ & & 11.00 & 1.00 & 3.00 & 8.00 & 6.00 & 12.00 & 0.00 & 5.00 & 1400 & 200 \\
\hline G. & & 0.20 & 0.10 & 0.20 & 0.07 & 0.30 & 0.30 & 0.04 & 0.40 & 0.04 & 0.10 \\
\hline G. & & 0.40 & 0.20 & 0.10 & 0.10 & 0.50 & 0.30 & 0.08 & 0.70 & 0.06 & 0.20 \\
\hline As & & 0.20 & 0.00 & 0.04 & 0.04 & 0.20 & 0.20 & 0.40 & 0.30 & 1.00 & 0.10 \\
\hline Se & & 0.30 & 0.20 & $0 \infty$ & 0.0 & 0.60 & 040 & 0.06 & 0.0 & 0.08 & 0.20 \\
\hline$B$ & & 0.30 & 0.20 & 0.00 & 00 & 0.40 & 0.40 & 0.00 & 0.00 & 0.06 & 0.20 \\
\hline$R b$ & & 0.70 & $1, \infty$ & 0.20 & 0.20 & 0.80 & 0.80 & 0.10 & 1.00 & 0.10 & 0.40 \\
\hline st & & 0.20 & 0.10 & 0.08 & 0.08 & 0.30 & 0.30 & 0.04 & 0.40 & 0.04 & 0.10 \\
\hline$Y$ & & 0.20 & 0.10 & 0.05 & 0.05 & 0.20 & 0.20 & $0 . \infty$ & 0.30 & 0.03 & 0.10 \\
\hline $2 r$ & & 0.40 & 0.20 & 0.10 & 0.40 & 2.00 & 2.00 & 0.00 & 0.0 & 0.20 & 0.20 \\
\hline $\mathrm{Nb}$ & & 0.20 & 0.10 & 0.06 & 0.07 & 0.30 & 1.00 & 004 & 0.30 & 0.01 & 0.10 \\
\hline $\mathrm{Mo}$ & & 0.00 & 0.50 & 0.20 & 0.00 & 36.00 & 1.00 & 0.20 & 1.00 & 0.20 & 0.50 \\
\hline Ru & & 0.70 & 0.40 & 0.20 & 0.20 & 0.00 & 0.50 & 0.10 & 1.00 & 0.10 & 040 \\
\hline$R_{h}$ & & 0.20 & 0.10 & $0 . \infty$ & 0.08 & 0.30 & 0.30 & 0.04 & 0.40 & 0.04 & 0.10 \\
\hline$P d$ & & 0.20 & 0.50 & 0.20 & 0.20 & 10 & 1.00 & 0.20 & $1 . \infty$ & 0.20 & 0.50 \\
\hline Ag & & 0.50 & 0.80 & 0.10 & 0.10 & 0.60 & 0.00 & 040 & 0.70 & 0.20 & 0.30 \\
\hline Cd & & 0.80 & 0.50 & 0.20 & 0.20 & 1.00 & 1.00 & 0.20 & 1.00 & 0.20 & 0.50 \\
\hline in & & 0.30 & 0.10 & 0.07 & 0.07 & 0.30 & 0.30 & 0.05 & 0.40 & 0.05 & 0.10 \\
\hline Sn & & 2.00 & 0.40 & 0.50 & 0.50 & 2.00 & 2.00 & 0.30 & 3.00 & 0.30 & 1.00 \\
\hline So & & 0.50 & 0.30 & 0.10 & 0.10 & $0 . \infty$ & 0.00 & 0.08 & 0.00 & 0.00 & 0.30 \\
\hline To & & 0.80 & 0.40 & 0.20 & 0.20 & 100 & 1.00 & 0.10 & 100 & 0.10 & 0.40 \\
\hline 1 & & 0.30 & 0.20 & 0.08 & 0.00 & 0.30 & 0.30 & 0.05 & 0.50 & 0.05 & 0.20 \\
\hline Cs & & 0.30 & 0.20 & 0.06 & 0.00 & 040 & 0.40 & 0.05 & 0.50 & 0.05 & 0.20 \\
\hline B. & & 0.40 & 0.20 & 0.10 & 0.10 & 0.50 & 0.50 & 0.07 & 0.70 & 0.07 & 0.20 \\
\hline 노 & & 0.30 & 0.20 & 0.08 & 0.08 & 040 & 0.40 & 0.05 & 0.50 & 0.05 & 0.20 \\
\hline$C$ & & 0.30 & 0.20 & 0.00 & 0.0 & 0.40 & 0.40 & 0.08 & 0.00 & 0.08 & 0.20 \\
\hline$P_{r}$ & & 0.30 & 0.20 & 0.08 & 0.0 & 0.40 & 0.40 & 0.05 & 0.30 & 0.05 & 0.20 \\
\hline No & & 1.00 & 0.70 & 0.40 & 040 & 2.00 & 2.00 & 020 & 2.00 & 0.20 & 0.70 \\
\hline $\sin$ & & 1.0 & 0.70 & 0.30 & 0.30 & 2.0 & 200 & 0.20 & 2.00 & 0.20 & 0.70 \\
\hline Eu & & 0.00 & 0.30 & 0.20 & 0.20 & 0.80 & 0.80 & 0.10 & 1.00 & 0.10 & 0.30 \\
\hline Gd & & 2.00 & 00 & 040 & 040 & 2.00 & 200 & 0.30 & 3.00 & 0.30 & 0.0 \\
\hline To & & 0.30 & 0.20 & 0.10 & 010 & 040 & 0.40 & 0.08 & 0.00 & 0.00 & 0.20 \\
\hline Dy & & 1.00 & 0.70 & 0.30 & 0.30 & 20 & 2.00 & 0.20 & 2.00 & 0.20 & 0.70 \\
\hline +o & & 0.40 & 0.20 & 0.10 & 0.10 & 040 & 0.40 & 0.08 & 0.60 & 0.00 & 0.20 \\
\hline Er & & 1.00 & 0.00 & 0.30 & 0.30 & 2.00 & 1.00 & 020 & 2.00 & 0.20 & $0 . \infty$ \\
\hline$T m$ & & 0.40 & 0.20 & 0.10 & 0.10 & 0.40 & 0.50 & 0.07 & 0.00 & 0.07 & 0.20 \\
\hline$Y b$ & & 1.00 & 0.00 & 0.30 & 0.30 & 1.00 & 1.00 & 0.20 & 200 & 0.20 & 0.00 \\
\hline $\mathrm{Lu}$ & & 0.40 & 0.20 & 0.10 & 0.10 & 0.50 & 0.50 & 0.07 & 0.00 & 0.07 & 0.20 \\
\hline $\mathrm{H}$ & & 1.00 & 0.80 & 040 & 010 & 2.00 & 2.00 & 0.30 & 2.00 & 0.30 & 0.80 \\
\hline $\mathrm{Ta}$ & & 1.00 & 200 & 0.30 & 030 & 1.00 & 2.00 & 0.70 & 6.00 & 070 & 1.00 \\
\hline$w$ & & 1.00 & 0.70 & 0.40 & 040 & 2.00 & 2.00 & 0.20 & 2.00 & 0.20 & 0.70 \\
\hline Re & & 060 & 040 & 0.20 & 0.20 & 0.80 & 0.80 & 0.10 & 100 & 0.10 & 040 \\
\hline$a$ & & 1.00 & 0.60 & 0.30 & 0.30 & 2.00 & 1.00 & 0.20 & 2.00 & 0.20 & 0.00 \\
\hline 18 & & 0.70 & $040^{\circ}$ & 020 & 020 & 2.00 & 0.80 & 0.10 & 100 & 010 & 040 \\
\hline$P$ & & 100 & 0.70 & 0.30 & 030 & $2 \infty$ & 2.0 & 0.20 & 2.00 & 0.20 & 0.70 \\
\hline Au & & 1.00 & 070 & 040 & 0.40 & 0.80 & 2.00 & 0.20 & 2.00 & 0.20 & 0.70 \\
\hline$H_{0}$ & & 1.00 & 080 & 0.40 & 040 & 1.00 & 200 & 0.30 & 2.00 & 0.30 & 0.80 \\
\hline$\pi$ & & 0.00 & 0.30 & 0.20 & 020 & 0.80 & 0.00 & 0.10 & 1.00 & 0.10 & 0.30 \\
\hline$P b$ & & 0.00 & 0.50 & 0.20 & 020 & 1.00 & 1.00 & 0.20 & 9.00 & 0.20 & 0.50 \\
\hline Bi & & 0.40 & 0.20 & 0.10 & 0.10 & 0.00 & 0.0 & 0.00 & 0.70 & 0.06 & 0.20 \\
\hline Th & & 0.30 & 0.30 & 0.10 & 0.10 & 0.00 & 0.00 & 0.00 & 0.80 & 0.00 & 0.30 \\
\hline
\end{tabular}


Currently, Y-12 does not have an official ${ }^{232} U$ acceptance standard. However, HEU containing up to $40 \mathrm{ppb}{ }^{232} \mathrm{U}$ has been accepted and is currently being stored. Some studies have been made in which acceptance of HEU containing up to $100 \mathrm{ppb}^{232} \mathrm{U}$ was considered. However, no firm decision was made in the studies.

\section{Plutonium Contamination}

Alpha counting for plutonium isotopes revealed the presence of both ${ }^{239} \mathrm{Pu} /{ }^{240} \mathrm{Pu}$ and ${ }^{238} \mathrm{Pu}$ in all of the samples. (The activity reported for ${ }^{239} \mathrm{Pu}$ is the sum of that for ${ }^{239} \mathrm{Pu}$ and ${ }^{240} \mathrm{Pu}$ since the alpha energies for the two isotopes are quite close.) Although plutonium is present on the samples, the quantities are all well within Y-12 proposed specifications for material acceptance criteria. The proposed specification is that the ratio of total plutonium alpha to total uranium alpha activity is less than or equal to 0.0075 or $0.75 \%$. Table 1 shows that these samples are at least a factor of 10 less than the proposed specification.

Y-12 is currently storing some uranium having plutonium concentrations up to $1 \mathrm{ppm}$. Based on nominal compositions for weapons grade plutonium and nominal U.S. weapons HEU composition, the activity ratio for this material would be about 0.0082 or $0.82 \%$.

Based on the ratio of measured alpha activity (and the derived atom ratios) for the ${ }^{238} \mathrm{Pu}$ and ${ }^{239} \mathrm{Pu}$ sources, there appears to be at least two different sources for the plutonium contamination in these samples. The high ${ }^{238} \mathrm{Pu}$ contamination in the uranium metal samples may indicate that this material may have been used for a different application than the uranium/beryllium fuel rods. The ${ }^{238} \mathrm{Pu}$ atom ratio $(0.082$ to 0.11$)$ in the plutonium appears to be too low to indicate a ${ }^{238} \mathrm{Pu}$ heat source application (which would be about 0.80 ), but is too high to be from either a normal light-water reactor or a liquid metal fast breeder reactor (which would be about 0.01 to 0.04 ). However, some preliminary calculations indicate that the irradiation of either HEU or low-enriched uranium (LEU) containing small amounts of ${ }^{237} \mathrm{~Np}$ (for HEU, ${ }^{237} \mathrm{~Np}$ concentrations of 0.015 to 0.025 atom \%, and for LEU concentrations of 0.2 to 0.3 atom \%) can make plutonium having ${ }^{238} \mathrm{Pu}$ in the observed concentration range. There is no information indicating why this contamination should be present in the HEU metal sample. In the remaining samples, the plutonium contamination and the ${ }^{238} \mathrm{Pu}$ concentration could be attributed to cross-contamination of the HEU with weapons grade plutonium either in the weapon or during dismantlement/disassembly operations.

\section{Trace Metal Analyses}

The trace metal analyses done for this project are summarized in Table 2. First, note that with the exception of those element concentrations labeled ' $>\mathbf{x x x x}$, all other concentrations are maximum values and they could very well be less than the reported values.

As expected, all the samples showed high concentrations of beryllium. Otherwise, all the high concentrations noted were in the standard common elements $\mathrm{Mg}, \mathrm{Si}, \mathrm{S}, \mathrm{Cl}, \mathrm{K}, \mathrm{Ca}, \mathrm{Cr}, \mathrm{Mn}, \mathrm{Fe}, \mathrm{Ni}$, and $\mathrm{Cu}$. Even in the concentrations noted, none of these pose a health hazard. All the samples had significant quantities of $\mathrm{Zn}$, the maximum concentration being $14 \mathrm{ppm}$. The remaining elements, with the exception of Mo in Sample No. 79781, are generally below 2 ppm, well below any potential health hazard.

With the exception of beryllium, there are no trace metals in these HEU samples that are of any significant health hazard. 


\section{ACKNOWLEDGMENTS}

I would like to acknowledge the good cooperation and prompt analysis of these samples by the Quality Service Division of the Y-12 Analytical Laboratories. Especially helpful were J. H. Hamilton, E. E. Dukes, and J. B. Wilson. 


\section{DISTRIBUTION}

1-11. Martin Marietta Energy Systems, Inc.

J. J. Bedell

S. O. Cox

E. H. Gift (PNL)

J. A. Kreykes

A. K. Lee ( 2 for OSTI) (3)

L. G. Loden

A. W. Riedy

J. D. Stout

R. E. Upchurch

Y-12 Central Files (RC)

12-16. U.S. Department of Energy

Oak Ridge Operations

D. Bruner, (DOE/MD) 
Enclosure 1

Letter: Bostock to Spence

Dated May 15, 1995
HECEIVED

DEC 281995

OSTI

\title{
"Project Sapphire Data Summary in Response to DOE/ORO-DOE/HQ Teleconference on December 21, 1994"
}

The following data are provided per agreement with DOE/ORO and DOE/HQ to provide further information concerning the material and nuclear properties of the Project Sapphire material that is now safely stored at the Y-12 Plant in Oak Ridge, Tennessee. These data provide detailed analyses of samples evaluated at the Y-12 Plant Laboratory (see Enclosure 2), a summary of Health Physics measurements of the DOT 6M-2R containers and some of the inner stainless steel containers, a description of the nondestructive assay (NDA) measurement techniques used to evaluate the U-235 assay and uranium content of a majority of the stainless steel cans, and finally hydrogen analysis data.

Enclosure 2 describes the analytical results of 11 samples (representing eight different Kazakhstani containers) of Project Sapphire material that were analyzed at the Y-12 Plant from April to July 1994. These samples provided the initial data on the following material forms: uranium metal, $\mathrm{UO}_{2}$ powder, uranium-beryllium oxide powder (machining scrap), and uraniumberyllium alloy

\section{Summary of Health Physics Data}

The following information was extracted from the Health Physics Container Survey records for each DOT $6 \mathrm{M}-2 \mathrm{R}$ container. These records specifically list the readings taken for Alpha and Beta/Gamma surface contamination, as well as Beta/Gamma and Neutron dose rates at the container surfaces and at a distance of 1 meter. Due to the urgency to provide this information to $\mathrm{DOE} / \mathrm{HQ}$ on a timely basis it is being provided in summary form. In summary, the data are as follows:

\author{
Alpha $\left(\mathrm{dpm} / 100 \mathrm{~cm}^{2}\right)$ \\ Max. Fixed Plus Removable $-<250$ \\ (Removable) Low - 0 \\ (Removable) High - 24 \\ Beta/Gamma (dpm/100 $\mathrm{cm}^{2}$ ) \\ (Removable) - < 120 \\ Beta/Gamma (mR/hr) \\ (at contact) Low -0.0 \\ (at contact) High -0.7
}


Page 2
(at 1 meter) Low -0.0
(at 1 meter) High -0.2
Neutron (mrem/hr)
(at contact) Low - 0
(at contact) High - 1.0
(at 1 meter) Low - 0
(at 1 meter) High -0.5

Radiation measurements were also taken of some of the stainless steel cans of repackaged Kazakhstani material prior to insertion into DOT $6 \mathrm{M}-2 \mathrm{R}$ containers to establish the dose rates for the various material forms. These dose rates are summarized below:

\section{Material Type}

HEU metal

HEU Oxides $\left(\mathrm{UO}_{2}, \mathrm{U}_{3} \mathrm{O}_{8}\right.$, or $\left.\left.\mathrm{UO}_{3}\right)\right)$

Uranium-beryllium alloy rods

Uranium-beryllium alloy scrap

Uranium dioxide-beryllium oxide rods

HEU-contaminated graphite

Laboratory Salvage

\section{Maximum Dose Rates}

$8 \mathrm{mrem} / \mathrm{hr}$

4-6 $\mathrm{mrem} / \mathrm{hr}$

$3.5 \mathrm{mrem} / \mathrm{hr}$ (neutron), $3.5 \mathrm{mrem} / \mathrm{hr}$ (gamma)

$4.8 \mathrm{mrem} / \mathrm{hr}$ (neutron), $4.2 \mathrm{mrem} / \mathrm{hr}$ (gamma)

No measurements recorded

No measurements recorded

No measurements recorded

\section{Summary of Nondestructive Assay Measurement Techniques}

Two types of NDA assay measurements were performed in Kazakhstan on the materials after they were repackaged into stainless steel, crimp sealed cans: (1) a neutron counting technique and (2) a gamma spectroscopy technique using a Davidson Multichannel Analyzer. The data from the NDA measurements are not tabulated in this document since the results either indicated the mass of uranium per can or the uranium-235 enrichment level for each can and these data would fill dozens of pages and be of limited value for a request for proposals. However, a brief description of each NDA technique used is provided below:

Uranium Metal Measured with Davidson Portable Multichannel Analyzer (PMCA) and Sodium Iodide (NaI) detector to confirm enrichment. Confirmatory measurements ranged from $80-86 \%$ and declared values were on the order of $89 \%$.

Uranium Oxide
Measured with Davidson Portable Multichannel Analyzer (PMCA) and Sodium Iodide (NaI) detector to confirm enrichment. Confirmatory measurements ranged from $83-86 \%$ and declared values were on the order of $89 \%$. 
Page 3

Uranium-Beryllium Alloy Rods Beryllium Oxide Rods

U-Be Residue

HEU Contaminated Graphite

Laboratory Salvage
Uranium Oxide-

Uranium-234 is enriched proportionally with Uranium-235. Uranium-234 is a strong alpha emitter, which in the presence of beryllium leads to an alpha-n reaction and an increased neutron flux that can be measured with a SNAP detector. The weight and physical dimensions of several different weight percent rod batches were measured to determine the density of the batches. The density correlates to within about $1 \%$ of the uranium-beryllium (U-Be) ratio. Their declared enrichment was assumed to be correct, the U-Be ratio was confirmed as described above, and several "standards" were made by filling one of our cans one-quarter full and measuring it with the SNAP detector, then one-half full and measuring, and then completely full and measuring it, This was repeated over the range of different $U$ $B e$ ratios. The grams of uranium proved to be proportional to the net neutrons counted by the SNAP. The slope of the line was essentially the same for all U-Be ratios with a corresponding shift in the intercept. The method is capable of measuring the grams of uranium in a can to within $10 \%$, relative.

Measured with a Davidson Portable Multichannel Analyzer (PMCA) and sodium iodide $(\mathrm{NaI})$ using a previously calibrated point source measurement.

The SNAP detector was used to measure the neutrons emitted in the same manner as above, utilizing the same linear equation it can confirm the uranium content of a can to within $+/-10 \%$, relative.

Measured with a Davidson Portable Multichannel Analyzer (PMCA) and Sodium Iodide $(\mathrm{NaI})$ using a previously calibrated point source measurement.

The SNAP detector was used to measure the neutrons emitted in the same manner as above.

\section{Hydrogen Analysis}

The Sapphire materials were analyzed for hydrogen content on a statistical basis to comply with the regulatory requirements of the U.S. Department of Transportation's Competent Authority Certification for the Type B Fissile Radioactive Materials Package Certificate USA/0002/X (Note: This container is also called the DOT 6M-2R). This certificate requires the shipper to certify that the hydrogen to uranium-235 ratio is less than or equal to three for any 
uranium compounds. Therefore, this applied to all the materials, except the HEU metal. Samples of the uranium compounds, listed previously, were taken on a statistical basis from the Kazakhstani containers and analyzed for hydrogen content using a laboratory induction furnace and hydrogen trapping technique. Only a few cans of material were packaged with an $\mathrm{H} / \mathrm{X}$ ratio greater than three and these cans were shipped with other cans that had H/X substantially less than three, so the total $\mathrm{H} / \mathrm{X}$ ratio for any $6 \mathrm{M}-2 \mathrm{R}$ container never exceeded the limit. 